\title{
Collembolan Density and Diversity in a Forest and an Agroecosystem
}

\author{
D. Paul ${ }^{*}$, A. Nongmaithem, L. K. Jha
}

Department of Environmental StudiesNorth Eastern Hill University, Shillong, India

Email: "pauld97@rediffmail.com

Received June $17^{\text {th }}, 2011$; revised July $22^{\text {nd }}, 2011$; accepted July $22^{\text {nd }}, 2011$

\begin{abstract}
:
Collembola, commonly called "springtails" are wingless soft-bodied hexapods that are usually between 1 and 3 millimetres in length and occur in varying habits such as, soil surface and litter, under rocks or the bark of trees. The great majority develop in soil, feeding on fungi, bacteria, algae and decaying plant matter, and along with other soil fauna constitute the decomposer community. The present study examines the diversity, density, and seasonal variation patterns of collembolan fauna under two different land uses, as evidenced in a forest and an agroecosystem. Results indicate that both densities and diversity of collembola was higher in the forest than in the agroecosystem. Seasonal fluctuation exhibited an increase from spring to summer and autumn and a decrease during winter. The coorelation patterns with different chemo-edaphic factors did not show any specific trend.Indices of diversity and significant correlation values are discussed in light of landuse.
\end{abstract}

Keywords: Collembola, Biodiversity, Forest, Agroecosystem

\section{Introduction}

Soil as a habitat contains the most diverse assemblages of living organisms. Collembola, commonly known as springtails, are small wingless soft-bodied hexapods that are usually between 1 and 3 millimetres in length, generally found on or near the soil surface and in the litter, under rocks or the bark of trees. They are usually associated with decaying organic matter, some species even found inhabiting the nests of ants and termites [1]. They are the most abundant insects found all over the world in a great variety of habitats, and densities as high as 200,000 individual per square metre have been recorded [2]. They have varied food habits, with species being detritivores, microbivores, coprovores and saprovores. Collembola together with other soil arthropods such as acari constitute an important component of soil mesofauna in almost all terrestrial ecosystems [3], and are indispensable in decomposition of organic matter, maintenance of soil physical structure, and efficient nutrient cycling. Although bulk of decomposition is attributed to microbial activities, soil fauna are important in conditioning the litter and in stimulating microbial activities [4]. Such activities are vital in the functioning of ecosystems and maintenance of soil health and above ground productivity, both in natural (e.g. Forest) and human al- tered (e.g. Agriculture) ecosystems.

Temperature and moisture are two of the most important environmental factors affecting populations of soildwelling collembola [5]. Soil moisture gradient and changes in soil temperature were observed to play a significant role in seasonal fluctuation and distribution of collembola [6-10]

Any land use which affects the soil structure or alters the soil chemistry affect the soil fauna. Land use change alters the below ground physico-chemical characteristics, often leading to loss of biodiversity and concomitant depletion of soil nutrients. Collembola richness and diversity decreased along a gradient of different land uses, from natural forest passing through mixed use landscape and agricultural dominated landscapes [11] Different agricultural practices also influences the biodiversity of microarthropod communities such that greater biodiversity is observed in minimum tillage systems compared to deep tillage systems [12]. Such analysis of the effects of different land-uses on diversity and species richness and the distribution pattern of collembola could serve as a potential bioindicator of land-use changes [13]. Studies on collembolan diversity may be helpful in the development of conservation strategies and monitoring of natural and human-impacted areas [14]. 
The present study is intended to analyze the diversity, density, and seasonal variation of collembola under two different land uses, represented by a forest and an agroecosystem.

\section{Materials and Methods}

The present investigation was carried out in a pine forest and an agroecosystem in the vicinity of North-Eastern Hill University, Shillong, the state capital of Meghalaya which lies between $25^{\circ} 4^{\prime} \mathrm{N}$ to $26^{\circ} 10^{\prime} \mathrm{N}$ latitudes and $89^{\circ} 48^{\prime} \mathrm{E}$ to $92^{\circ} 50^{\prime} \mathrm{E}$ longitudes.

A seasonal sampling was carried out for each of the four seasons i.e. spring, summer, autumn and winter for one annual cycle i.e. from March 2008 to February 2009. During each sampling occasion, triplicate samples were collected from each of the two sampling sites i.e. forest and agroecosystem. The soil samples were collected with a soil core of $5 \times 5 \mathrm{~cm}^{2}$ in surface area and at a depth of $0-10 \mathrm{~cm}$. The forest soil samples also included the overlying litter, which was absent in the agroecosystem soil samples. The samples were tagged and sealed, transported to the laboratory and extracted for soil fauna for 48 hours using modified high-efficiency Tullgren extractor. The extracted fauna were sorted, identified and counted. Alongside, soil samples were also collected for determining the $\mathrm{pH}$, conductivity, moisture content and pore space. Soil temperature was recorded at site during sampling.

Measures of species diversity (Simpson's index) and the correlation coefficient were analysed by using PASTPoint pattern analysis 1.99 .

\section{Results and Discussion}

\subsection{Physico-Chemical Factors}

$\mathrm{pH}$ of forest soil ranged between 5.57 and 6.02, indicating that the soils are acidic in nature. The seasonal trend followed is a slight increase during spring and summer and then a gradual decrease during autumn and winter. Electrical conductivity of forest soil was observed to range between $6.42 \mu \mathrm{S}$ and $11.45 \mu \mathrm{S}$. The seasonal variation did not show any specific trend (Figure 1). A similar trend of seasonal variation of soil $\mathrm{pH}$ was observed in the agroecosystem (Figure 2) as in forest, where it declined from autumn towards winter season. The values ranged between 5.00 and 6.30. As for electrical conductivity the values ranged between $11.68 \mu \mathrm{S}$ and $36.60 \mu \mathrm{S}$ showing a slight increase from spring through summer and autumn and then a slight decrease during winter.

Soil temperature increased from spring through summer and gradually declined from autumn to winter. Lowest soil temperature of $14.7^{\circ} \mathrm{C}$ was recorded during

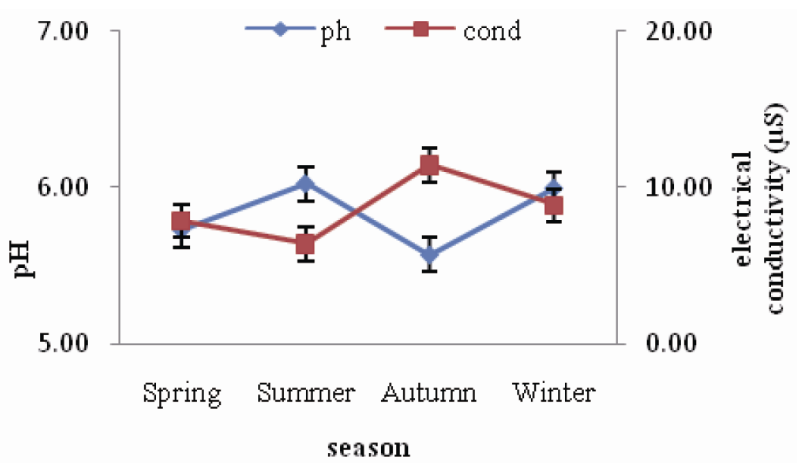

Figure 1. Seasonal fluctuation of pH and electrical conductivity in forest.

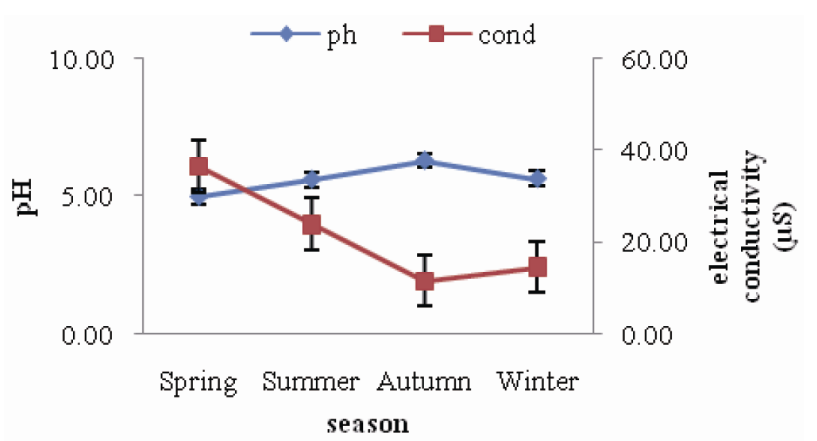

Figure 2. Seasonal fluctuation of pH and electrical conductivity in agroecosystem.

winter and highest temperature of $23.03^{\circ} \mathrm{C}$ was recorded during summer. Soil moisture content gradually decreases from spring peak of $47.38 \%$ to a winter low of $23.76 \%$ Soil porosity was observed to be lower during spring and summer and gradually increase during autumn and winter with values ranging between $67.05 \%$ and $70.39 \%$ (Figure 3).

Soil temperature, soil moisture and porosity of agroecosystem are represented in Figure 4. Lowest soil temperature recorded was $14.93^{\circ} \mathrm{C}$ during winter and highest temperature was $23.62^{\circ} \mathrm{C}$ recorded during summer. Moisture content increased from spring to a summer peak of $58.03 \%$ subsequently decreasing gradually to the lowest value of $37.61 \%$ in winter. The soil porosity was more or less uniform throughout the seasons with values ranging between $71.86 \%$ and $74.48 \%$.

Although soil temperature of forest and agroecosystem showed very little difference, the agroecosystem soil revealed an overall higher range. Soil moisture content and porosity clearly showed a higher range in agroecosystem as compared to the forest soil reflecting the effects of tillage. Soil conductivity ranges were also higher in the agroecosystem probably as a result of the use of organic manure. 


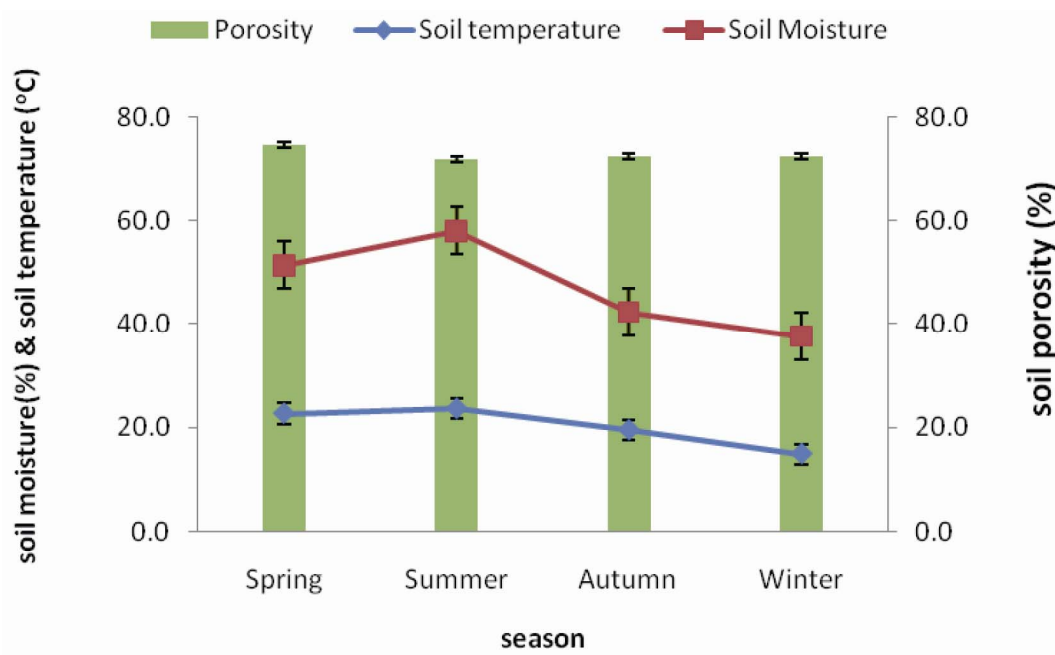

Figure 3. Seasonal fluctuation of soil porosity, soil temperature and soil moisture in forest.

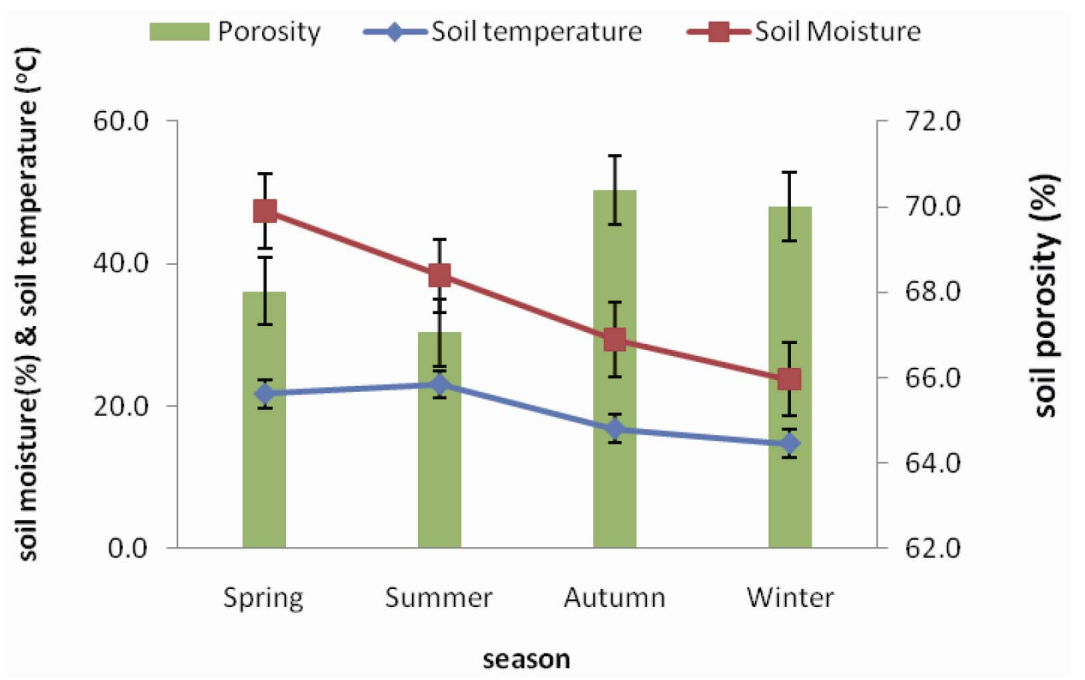

Figure 4. Seasonal fluctuation of soil porosity, soil temperature and soil moisture in agroecosystem.

\subsection{Species Composition and Diversity}

A total of ten (10) species of collembola were recorded in the pine forest and nine (9) in agroecosystem soil as shown in Table 1. The species composition was found to be the same in forest and agroecosystem, except for the absence of Dicranocentroides $s p$. in agroecosystem soil. Similarity in species composition may be explained by the nature of the terrain of the study sites. The forest is located on a hillock which merges into the agroecosystem located in the adjoining valley. It is speculated that the fauna are probably washed down by flowing rain water from forest soil into the agroecosystem where they colonise. Figure 5 illustrates the diversity (Simpson's index) of collembolan in forest and agroecosystem. Diversity of collembolan in forest exhibited a seasonal trend of increasing values from spring $(0.40)$ to summer and autumn ( 0.68 and 0.76 respectively) when $\mathrm{pH}$, soil
Table 1. Species composition of collembola in forest and agroecosystem.

\begin{tabular}{cccc}
\hline S1. No. & Collembola & Forest & Agroecosystem \\
\hline 1. & Hypogastrura sp. & + & + \\
2. & Xenylla $s p$. & + & + \\
3. & Folsomia $s p$. & + & + \\
4. & Seira $s p$. & + & + \\
5. & Lepidicyrtus $s p$. & + & + \\
6. & Cyphoderus sp. & + & + \\
7. & Dicranocentroides sp. & + & - \\
8. & Callyntrura sp. 1 & + & + \\
9. & Callyntrura sp. 2 & + & + \\
10. & Sphyrotheca $s p$. & + & + \\
\hline
\end{tabular}




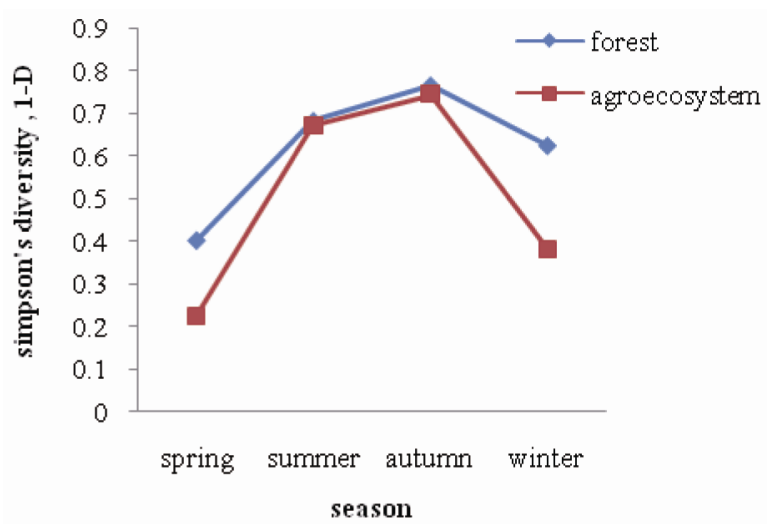

Figure 5. Seasonal fluctuation of diversity in forest and agroecosystem.

temperature and moisture were at a higher range, and then decreased during winter $(0.62)$ when soil temperature and moisture was lower. A similar trend of seasonal variation of diversity was observed in agroecosystem where the diversity values ranged between 0.23 recorded during spring and 0.74 recorded during autumn. Collembola declines in numbers through the dry season and then increased during the wet season $[15,16]$. A marked difference in diversity between forest and agroecosystem was observed during spring and winter, whereas, the values were more or less same during summer and autumn. Overall, the forest harboured a higher diversity of collembola as compared to the agroecosystem probably reflecting the higher intensity of disturbance in the latter.

A similar finding was made, where, collembolan diversity, abundance and species richness decreased along a gradient of soil-uses ranging from a forest with minimum intervention to an agricultural site completely exposed to anthropogenic disturbances passing through managed forest and grasslands [13]. Further, in forest ecosystems, the primary producer-decomposer systems determine the abundances of collembola through the availability of habitat provided by the amount of litter and organic layers in the soils [15]

\subsection{Density}

Figure 6 illustrates the mean total collembolan density in forest and agroecosystem soil. Forest soil contained a higher density of collembola $\left(1,475\right.$ individuals $\left.\cdot \mathrm{m}^{-2}\right)$ all seasons combined, as compared to the agroecosystem $\left(1,289\right.$ individuals $\left.\cdot \mathrm{m}^{-2}\right)$. Highest density was recorded during summer in forest (2558 individuals $\cdot \mathrm{m}^{-2}$ ) and during autumn in agroecosystem $\left(3,244\right.$ individuals $\left.\cdot \mathrm{m}^{-2}\right)$. The lowest records of mean total density were during spring in forest $\left(876\right.$ individuals $\cdot \mathrm{m}^{-2}$ ) and agroecosystem $\left(896\right.$ individuals $\cdot \mathrm{m}^{-2}$ ). Land use intensification (land disturbance) negatively influences the abundance and spe-

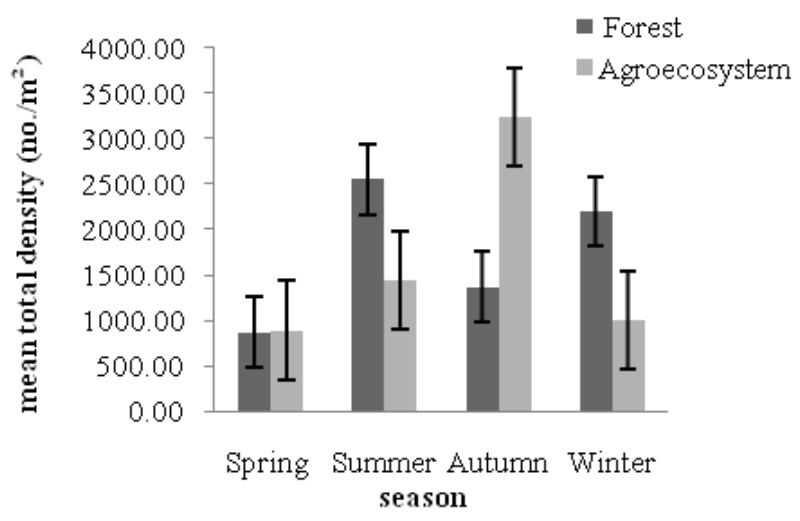

Figure 6. Mean total density of collembola in forest and agroecosystem.

cies richness of soil collembolan communities [16].

The percentage composition of collembolan species in forest and agroecosystem is depicted in Figures $\mathbf{7}$ and $\mathbf{8}$ respectively. Cyphoderus $s p$. accounted for the highest percent density in both forest and agroecosystem representing $21 \%$ and $30 \%$ of the total density respectively.

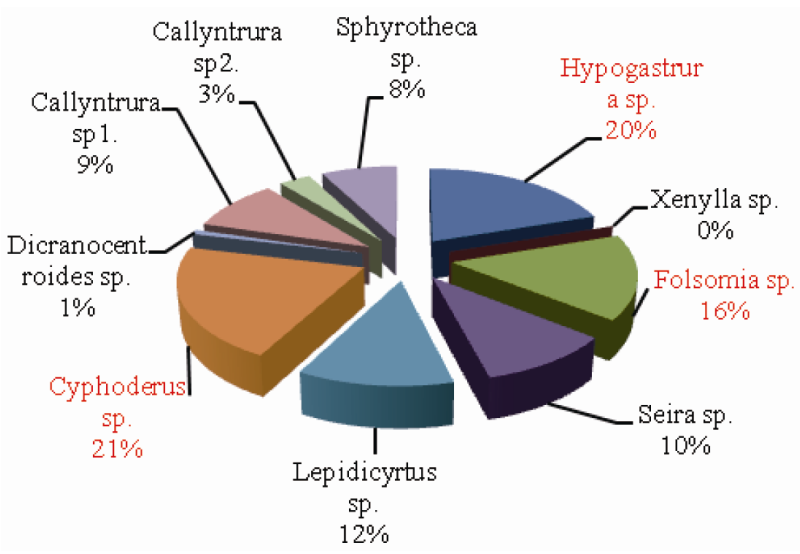

Figure 7. Percentage composition of Collembolan species in forest.

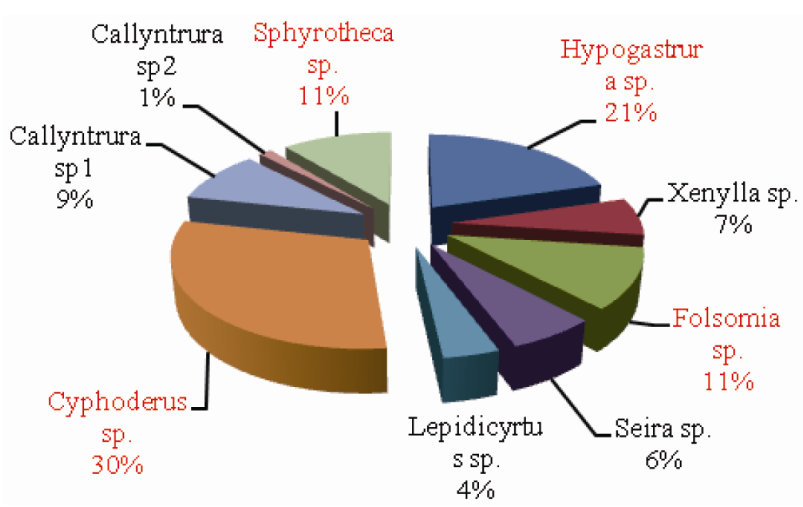

Figure 8. Percentage composition of Collembolan species inagroecosystem. 
This was followed by Hypogastrura sp. (20\% in forest and $21 \%$ in agroecosystem) and Folsomia sp. (16\% in forest and $11 \%$ in agroecosystem). Sphyrotheca $s p$. also constituted $11 \%$ of the total density in agroecosystem. On the whole, Cyphoderus sp., Hypogastrura sp. and Folsomia sp. were the dominant species.

\subsection{Correlation}

The seasonal assessment of correlation of collembolan diversity and density with the abiotic factors revealed a random pattern of positive and negative correlation. (Tables 2 to 5). Diversity and $\mathrm{pH}$ in forest showed a weak positive correlation (not significant), while electrical conductivity and soil temperature showed significant positive correlation with diversity $(\mathrm{p} \leq 0.05$ and $\mathrm{p} \leq 0.01)$. A significant negative correlation was observed between diversity and soil moisture and porosity $(\mathrm{p} \leq 0.05)$. In the agroecosystem, $\mathrm{pH}$ and soil temperature demonstrated a significant positive correlation with diversity $(\mathrm{p} \leq 0.05)$, while the other physico-chemical factors had a weak positive and weak negative correlation (not significant) with diversity. Collembolan density also exhibited a significant positive correlation with soil temperature $(\mathrm{p} \leq$ 0.05 ) in both forest and agroecosystem. Density and porosity were also positively correlated, $(p \leq 0.05)$ in forest. Density and $\mathrm{pH}$ in agroecosystem were negatively correlated $(\mathrm{p} \leq 0.05)$.

\section{Conclusions}

Diversity and density of collembola varies greatly with changes in physical and climatic conditions of an area. The overall diversity and density of collembola was higher in the forest as compared to the agroecosystem. This may be indicative of the higher intensity of disturbance in the agroecosystem as compared to the forest by way of tillage and irrigation which alter the soil structure

Table 2. Correlation between diversity of Collembola and physico-chemical factors in forest.

\begin{tabular}{|c|c|c|c|c|c|c|}
\hline Season & & $\mathrm{pH}$ & Electrical Conductivity $(\mu \mathrm{S})$ & Soil Temperature $\left({ }^{\circ} \mathrm{C}\right)$ & Soil Moisture (\%) & Soil Porosity (\%) \\
\hline \multirow{2}{*}{ Spring } & Diversity & 0.44 & -0.19 & $0.57^{* *}$ & 0.15 & 0.04 \\
\hline & $\mathrm{p}$ value & 0.07 & 0.45 & 0.01 & 0.55 & 0.87 \\
\hline \multirow{2}{*}{ Summer } & Diversity & 0.41 & $0.52^{*}$ & 0.25 & $-0.48^{*}$ & $-0.49^{*}$ \\
\hline & $\mathrm{p}$ value & 0.09 & 0.03 & 0.31 & 0.04 & 0.04 \\
\hline \multirow{2}{*}{ Autumn } & Diversity & 0.38 & $0.47^{*}$ & 0.14 & -0.33 & -0.24 \\
\hline & $\mathrm{p}$ value & 0.12 & 0.05 & 0.57 & 0.18 & 0.34 \\
\hline \multirow{2}{*}{ Winter } & Diversity & 0.25 & -0.13 & 0.06 & 0.15 & 0.12 \\
\hline & $\mathrm{p}$ value & 0.33 & 0.62 & 0.81 & 0.55 & 0.65 \\
\hline
\end{tabular}

( $\left.{ }^{*}\right)$ correlation coefficient significant at $\mathrm{p} \leq 0.05 .\left(^{* *}\right)$ correlation coefficient significant at $\mathrm{p} \leq 0.01$.

Table 3. Correlation between diversity of Collembola and physico-chemical factors in agroecosystem.

\begin{tabular}{|c|c|c|c|c|c|c|}
\hline Season & & $\mathrm{pH}$ & Electrical Conductivity $(\mu \mathrm{S})$ & Soil Temperature $\left({ }^{\circ} \mathrm{C}\right)$ & Soil Moisture (\%) & Soil Porosity (\%) \\
\hline \multirow{2}{*}{ Spring } & Diversity & $0.66^{*}$ & -0.45 & $0.60^{*}$ & 0.45 & 0.48 \\
\hline & $\mathrm{p}$ value & 0.02 & 0.14 & 0.04 & 0.15 & 0.11 \\
\hline \multirow{2}{*}{ Summer } & Diversity & -0.31 & 0.19 & 0.39 & -0.23 & 0.18 \\
\hline & $\mathrm{p}$ value & 0.33 & 0.55 & 0.20 & 0.46 & 0.57 \\
\hline \multirow{2}{*}{ Autumn } & Diversity & -0.08 & -0.07 & -0.25 & 0.17 & -0.29 \\
\hline & $\mathrm{p}$ value & 0.79 & 0.83 & 0.43 & 0.60 & 0.36 \\
\hline \multirow{2}{*}{ Winter } & Diversity & -0.10 & 0.20 & 0.25 & -0.20 & -0.35 \\
\hline & $\mathrm{p}$ value & 0.76 & 0.54 & 0.43 & 0.53 & 0.27 \\
\hline
\end{tabular}

() correlation coefficient significant at $\mathrm{p} \leq 0.05$. 
Table 4. Correlation between density of Collembola and physico-chemical factors in forest.

\begin{tabular}{|c|c|c|c|c|c|c|}
\hline Season & & $\mathrm{pH}$ & Electrical Conductivity $(\mu \mathrm{S})$ & Soil Temperature $\left({ }^{\circ} \mathrm{C}\right)$ & Soil Moisture (\%) & Soil Porosity (\%) \\
\hline \multirow{2}{*}{ Spring } & Density & -0.26 & -0.08 & $0.51^{*}$ & 0.10 & $0.50^{*}$ \\
\hline & $\mathrm{p}$ value & 0.29 & 0.74 & 0.03 & 0.70 & 0.03 \\
\hline \multirow{2}{*}{ Summer } & Density & 0.26 & 0.23 & 0.65 & 0.16 & 0.15 \\
\hline & $\mathrm{p}$ value & 0.30 & 0.35 & 0.00 & 0.52 & 0.56 \\
\hline \multirow{2}{*}{ Autumn } & Density & 0.39 & 0.82 & -0.01 & -0.42 & $-0.48^{*}$ \\
\hline & $\mathrm{p}$ value & 0.10 & 0.00 & 0.97 & 0.08 & 0.05 \\
\hline \multirow{2}{*}{ Winter } & Density & -0.34 & -0.34 & -0.05 & 0.26 & 0.25 \\
\hline & $\mathrm{p}$ value & 0.16 & 0.16 & 0.84 & 0.30 & 0.31 \\
\hline
\end{tabular}

(*) correlation coefficient significant at $\mathrm{p} \leq 0.05$.

Table 5. Correlation between density of Collembola and physico-chemical factors in agroecosystem.

\begin{tabular}{ccccccc}
\hline Season & & $\mathrm{pH}$ & Electrical Conductivity $(\mu \mathrm{S})$ & Soil Temperature $\left({ }^{\circ} \mathrm{C}\right)$ & Soil Moisture $(\%)$ & Soil Porosity $(\%)$ \\
\hline \multirow{2}{*}{ Spring } & Density & -0.30 & -0.51 & 0.21 & -0.46 & -0.05 \\
& $\mathrm{p}$ value & 0.35 & 0.09 & 0.51 & 0.13 & 0.88 \\
\multirow{2}{*}{ Summer } & Density & -0.65 & 0.36 & -0.07 & 0.06 & 0.50 \\
& p value & $\mathbf{0 . 0 2}$ & 0.25 & 0.82 & 0.86 & 0.10 \\
\multirow{2}{*}{ Autumn } & Density & -0.16 & -0.01 & 0.26 & -0.06 & -0.28 \\
& p value & 0.63 & 0.98 & 0.41 & 0.85 & 0.38 \\
\multirow{2}{*}{ Winter } & Density & 0.34 & -0.53 & 0.63 & 0.15 & -0.23 \\
& p value & 0.27 & 0.08 & $\mathbf{0 . 0 3}$ & 0.65 & 0.47 \\
\hline
\end{tabular}

() correlation coefficient significant at $\mathrm{p} \leq 0.05$.

and its chemical nature, depleting the available resources and making the soil less habitable and conducive for the growth and sustenance of soil fauna. The pattern of seasonal fluctuations of species diversity and density corresponded with changes in the physico-chemical factors as evidenced by the statistically significant correlations between the two entities. Higher species diversity and density was recorded during the spring and summer months when the soil temperature and soil moisture were on the higher range than autumn and winter months. Among the collembolan species recorded, Cyphoderus sp, Folsomia s, and Hypogastrura sp. contributed a relatively high percentage to total density in both the study sites. Temporally, they were encountered throughout the sampling period except for a few instances when they were absent. This implies that, these species dominate the total recorded population of collembola and have a wide range of tolerance (occurrence) to soil physicochemical perturbances.

\section{REFERENCES}

[1] http://www.ento.csiro.au/education/hexapods/collembola. html.
[2] S. Hopkin, "The Biology of the Collembola (Springtails): the Most Abundant Insects in the World," 2002. http:// www.fathom.com/feature/122603/

[3] J. Rusek, "Biodiversity of Collembola and Their Functional Role in the Ecosystem," Biodiverisity and Conservation, Vol. 12, 1998, pp. 1207-1219. doi:10.1023/A:1008887817883

[4] D. C. Coleman and D. A. Crossley, "Fundamentals of Soil Ecology," Academic Press, New York, 1996.

[5] W. II Choi, D. L. Moorhead, D. A. Neher and M. II. Ryoo, "A Modeling Study of Soil Temperature and Moisture Effects on Population Dynamics of Paronychiurus kimi (Collembola: Onychiuridae)," Biology Fertile Soils, Vol. 43, No. 1, 2006, pp. 69-75. doi:10.1007/s00374-005-0062-5

[6] S. K. Mitra, A. K. Hazra and A. K. Sanyal, "Ecology of collembola at the eden gardens, Calcutta," Ecological Bulletin (Stockholm), Vol. 25, 1977, pp. 539-544.

[7] H. A. Verhorf and A. J. van. Selm, "Distribution and Population Dynamics of Collembola in Relation to Soil Moisture," Holarctic Ecology, Vol. 6, 1983, pp. 378-394.

[8] P. K. Vatsauliya and J. R. B. Alfred, "Ecological Studies on Jhum Fallows (Meghalaya) with Special Reference to Soil Fauna," Records of the Zoological Survey of India Ocassional Paper, No. 149, 1993. 
[9] V. Huhta and S. M. Hanninen, "Effects of Temperature and Moisture Fluctuations on an Experimental Soil Microarthropod Community," Pedobiologia, Vol. 45, No. 3, 2001, pp. 279-286. doi:10.1078/0031-4056-00085

[10] E. Jucevica and V. Melecis, "Long-Term Effects of Climate Warming on Forest Soil Collembola," Acta Zoologica Lituanica, Vol. 15, No. 2, 2005, pp. 124-126.

[11] J. P. Sousa, T. Bolger, M. M. da Gama, T. Lukkari, J. F. Ponge, C. Simon, G. Traser, A. J. Vanbergen, A. Brennan, F. Dubs, E. Ivitis, A. Keating, S. Stofer and A. D. Watt, "Changes in Collembola Richness and Diversity Along a Gradient of Land-Use Intensity: A Pan European Study," Pedobiologia, Vol. 50, No. 2, 2006, pp. 147-156. doi:10.1016/j.pedobi.2005.10.005

[12] J. Cortet, D. Ronce, N. P. Balaguer, C. Beaufreton, A. Chabert, P. Viaux and J. P. C de Fonseca, "Impacts of Different Agricultural Practices on the Biodiversity of Microarthropod Communities in Arable Crop Systems," European Journal of Soil Biology, Vol. 38, No. 3-4, 2002, pp. 239-244. doi:10.1016/S1164-5563(02)01152-4
[13] J. P. Sousa, M. M. da Gama, C. Pinto, A. Keating, F. Calhoa, M. Lemos, C. Castro, T. Luz, P. Leitao and S. Dias, "Effects of Land-Use on Collembola Diversity Patterns in a Mediterranean Landscape," Pedobiologia, Vol. 48, No. 5-6, 2004, pp. 609-622. doi:10.1016/i.pedobi.2004.06.004

[14] M. P. Culik and D. Z. Filho, "Diversity and Distribution of Collembola (Arthropoda: Hexapoda) of Brazil," Biodiversity and Conservation, Vol. 12, No. 6, 2003, pp. 1119-1143. doi:10.1023/A:1023069912619

[15] D. Wiwatwitaya and H. Takeda, "Seasonal Changes in Soil Arthropod Abundance in the Dry Evergreen Forest of North-East Thailand, with Special Reference to Collembolan Communities," Ecology Research, Vol. 20, No. 1, 2005, pp. 59-70. doi:10.1007/s11284-004-0013-x

[16] J. J. Muturi, J. P. Mbugil, J. M. Mueke, J. Lagerlof, J. K. Mungatu, G. Nyamasyo and M. Gikungu, "Collembola Density and Diversity Along a Gradient of Land-Use Types in Embu District, Eastern Kenya," Tropical and Subtropical Agroecosystems, Vol. 11, 2009, pp. 361-369. 